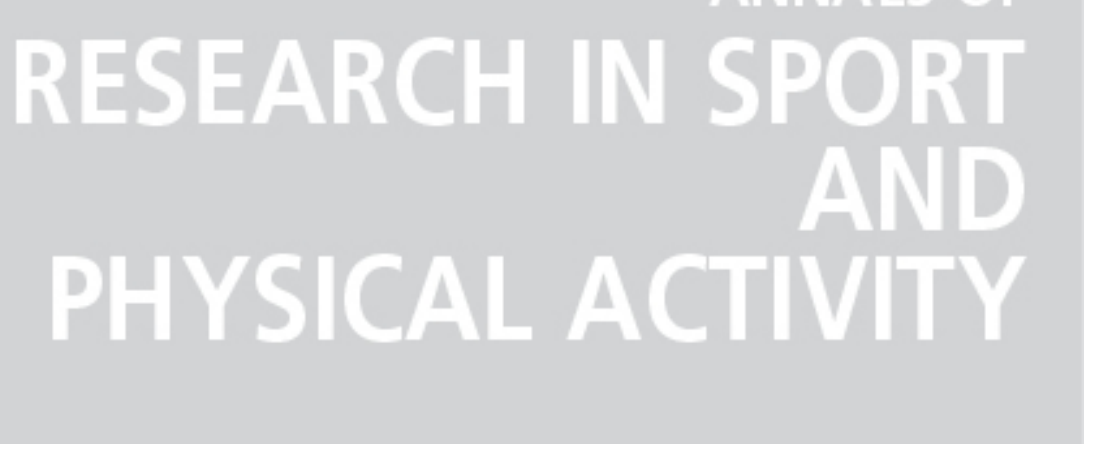

\title{
Anaphylaxis during physical exercise
}

Autor(es): $\quad$ Moura, A. L.; Faria, E.; Todo Bom, A.; Carrapatoso, I.

Publicado por: Imprensa da Universidade de Coimbra

URL

persistente: URI:http://hdl.handle.net/10316.2/44087

DOI: $\quad$ DOI:https://doi.org/10.14195/2182-7087_ex2018_24

Accessed : $\quad$ 26-Apr-2023 11:50:18

A navegação consulta e descarregamento dos títulos inseridos nas Bibliotecas Digitais UC Digitalis, UC Pombalina e UC Impactum, pressupõem a aceitação plena e sem reservas dos Termos e Condições de Uso destas Bibliotecas Digitais, disponíveis em https://digitalis.uc.pt/pt-pt/termos.

Conforme exposto nos referidos Termos e Condições de Uso, o descarregamento de títulos de acesso restrito requer uma licença válida de autorização devendo o utilizador aceder ao(s) documento(s) a partir de um endereço de IP da instituição detentora da supramencionada licença.

Ao utilizador é apenas permitido o descarregamento para uso pessoal, pelo que o emprego do(s) título(s) descarregado(s) para outro fim, designadamente comercial, carece de autorização do respetivo autor ou editor da obra.

Na medida em que todas as obras da UC Digitalis se encontram protegidas pelo Código do Direito de Autor e Direitos Conexos e demais legislação aplicável, toda a cópia, parcial ou total, deste documento, nos casos em que é legalmente admitida, deverá conter ou fazer-se acompanhar por este aviso. 


\section{ANNALS OF RESEARCH IN SPORT AND PHYSICAL ACTIVITY}




\title{
ANAPHYLAXIS DURING PHYSICAL EXERCISE
}

\author{
Moura A. L. ${ }^{1}$; Faria E. ${ }^{2}$; Todo Bom A. ${ }^{2}$; Carrapatoso I. ${ }^{2}$
}

KEYWORDS: Exercise-induced anaphylaxis. Wheat allergy. Omega-5 gliadin.

\section{BACKGROUND}

Exercise-induced anaphylaxis is a rare disorder in which anaphylaxis occurs during or following physical activity, and presents with severe allergic reaction involving multiple systems (cutaneous, respiratory, gastrointestinal and/or cardiovascular). A distinct subtype is characterized by onset of symptoms of anaphylaxis only if physical activity occurs associated with a specific food allergen ingestion.

\section{CLINICAL CASE}

We describe a case of a 59-year-old man with two episodes of anaphylaxis that occurred during physical activity - walking, after dinner time. In both episodes he presented with rhinoconjunctivitis, urticaria, angioedema, dyspnea and loss of consciousness. The meal consisted of vegetable soup and wheat based bread. The episodes occurred following coronary heart surgery and after making lifestyle changes: light dinners consisting of soup and bread, regular exercise (mainly, walks after dinner) and prescribed medication (furosemide, atorvastatin and aspirin). Physical exercise as well as cereals ingestion alone was tolerated. There was no previous history of allergic disorders.

He was admitted in our Immunoallergology Department for further investigation. Total IgE was elevated (443 IU/mL). Skin prick tests to aeroallergens and cereals were negative.

\footnotetext{
1 Immunoallergology Department, Coimbra Hospital and University Centre, Coimbra, Portugal; Member of Interest group Asthma and Allergy in Sports of the Portuguese Society of Allergy and Clinical Immunology (SPAIC).

2 Immunoallergology Department, Coimbra Hospital and University Centre, Coimbra, Portugal.

Email: al-moura@hotmail.com
} 
Prick-to-prick tests with bread flours were positive to wheat, rye, barley and corn (wheals diameter 8, 10, 4 and $4 \mathrm{~mm}$, respectively). Specific IgE was positive to wheat $(0,9 \mathrm{kU} / \mathrm{L})$, rye $(4,2 \mathrm{kU} / \mathrm{L})$ and the molecular component $\omega$-5-gliadin $(9,7 \mathrm{kU} / \mathrm{L})$.

These results strongly support the diagnosis of food dependent exercise-induced anaphylaxis (FDEIA). The foods most commonly implicated are wheat, shellfish, tomatoes, peanuts, and corn, though a wide variety of foods can be associated. A distinct subtype triggered by wheat ingestion is called wheat dependent exercise-induced anaphylaxis (WDEIA), which the major causative allergen is $\omega$-5-gliadin. Exercise-induced anaphylaxis to food allergens focuses on two levels of cofactor modulation: exercise increases the bioavailability and influences the distribution of certain allergens, and decreases the threshold for activation of mast cells and basophils.

The patient was advised to avoid eating wheat and rye 3 hours before and 1 hour after exercising. Patient education included detailed information on foods that may contain hidden cereals and a written emergency plan including self-injectable adrenaline. The patient was advised to avoid other nonsteroidal anti-inflammatory drugs (NSAIDs) and aspirin was replaced by clopidogrel. In the last 3 years he continued to eat corn, barley, oats, and rice. With the avoidance measures taken, no more allergic symptoms or anaphylactic episodes occurred.

\section{CONCLUSION}

This case is an example of WDEIA where elicitation of anaphylaxis occurred in the presence of physical exercise and daily intake of aspirin.

Identifying both the trigger allergen and the dependence on cofactors is essential in allergologist's patient routine assessment, which help to avoid possibly life-threatening anaphylactic events in the future. 